\title{
Is it time to let go? The Best Loser System in Mauritius
}

\author{
Yonatan Fessha (1), Nora Ho Tu Nam (2) \\ (I) Department of Public Law and Jurisprudence \\ University of the Western Cape, South Africa \\ (2) Centre for Human Rights, University of Pretoria, South Africa
}

\begin{abstract}
As Mauritius was moving towards independence, one contested issue was the electoral system to be adopted. Minority groups were wary of any electoral system which would allow for a Hinduhegemony and which would leave them unable to access power. To respond to this anxiety, Mauritius adopted the best loser system (BLS), a unique system of ethnic representation in the national parliament. This contribution examines how the adoption of BLS, has over the years, contributed to the management of ethnic diversity. More importantly, it examines the current debate regarding the contemporary relevance of BLS to today's Mauritius. At times heavily criticized for its communal and ethnic undertones, BLS has ensured continued minority representation in parliament. The article argues that one must be cautious about dismissing the relevance of inclusive institutions such as BLS as such an attitude might well undermine the move towards a more united Mauritius.
\end{abstract}

Key words: best loser system, parliamentary representation, ethnicity, minorities, Mauritius

\section{Introduction}

With over 15 language groups and the four major religions of the world inhabiting a territory of only $2,040 \mathrm{~km}^{2}$, social cohesion is not something that can be taken for granted in Mauritius. In fact, in his report to the British government before the accession of Mauritius to independence, John Meade, an Economics Nobel Prize winner, predicted the collapse of the island (Yusuf, 2012;7). For Meade, the small size of the island and its ethnic and religious diversity made the prospect of durable peace and economic progress unlikely. History, however, proved Meade wrong. Mauritius has not only enjoyed strong economic development, but has also managed to sustain peaceful coexistence amongst diverse communities.

The harmonious coexistence of the different communities in Mauritius is largely attributed to government policies that have taken the ethnic diversity of the island seriously. The measures taken by successive governments range from the symbolic gesture of ensuring the equal distribution of public holidays among the different cultural communities to the teaching of the different ancestral languages in all primary schools and the adoption of a neutral language, English, as the official language of the state. There is 
also an equal appreciation that well-designed rules facilitating political participation and representation are an important component in the management of conflicts in a state with competing ethnic interests. In this regard, Mauritius has adopted what is known as the best loser system (BLS), a unique system of ethnic representation in the national parliament.

This contribution examines the impact of BLS on the accommodation of ethnic diversity in Mauritius. It examines how the adoption of BLS has, over the years, contributed to the management of ethnic diversity. More importantly, it examines the ongoing debate on the contemporary relevance of BLS to today's Mauritius. The article commences the discussion with a brief description of the ethnic and religious diversity that characterises Mauritian society. This is followed by a brief historical background on the circumstances that led to the adoption of BLS. The functioning of BLS, as expounded in the Constitution of Mauritius, is then explained. The article then turns to its main business and focuses on the contribution of BLS to the management of ethnic diversity in Mauritius.

\section{Multi-cultural Mauritius}

Uninhabited at the time of its discovery, Mauritius has been populated by successive waves of migration. People from Europe, Africa and Asia have, over the years, settled in Mauritius, creating a multi-ethnic, multi-linguistic and multi-faith island. The mosaic nature of the Island cannot be overemphasised. As one author observed, "[a] leisurely walk through the capital, Port-Louis, may bring one past, within half an hour or so, a Buddhist pagoda, a Sunni mosque, and Anglican church and a Catholic one, and two Hindu temples - one North Indian, one Tamil" (Eriksen, I997; 178).

There is little agreement regarding the cleavage that underlies Mauritian society. For some, the dominant cleavage runs along the line of religion. For others, it is ethnicity. However, as Eriksen noted, even if one takes ethnicity as the most important cultural marker that captures the socio-cultural diversity in Mauritius, there is no consensus as to the 'classification of ethnic categories' as "ethnic classification in Mauritius is highly ambiguous and context-dependent" (Eriksen, I992; I69). According to the 1972 population census, the last census in which the Mauritian people were requested to declare their ethnicity, $52 \%$ of the population is Indo-Mauritian, which includes the Hindus, the Tamils, the Marathis, the Telegus and the Gujaratis; $27 \%$ of the population is Creole while Muslims account for $\mathrm{I} 6 \%$ of the population. The rest of the population is divided between people of Chinese origin accounting for $3 \%$ and the Franco-Mauritians accounting for $2 \%$. The ambiguity of this classification, however, becomes immediately clear when one examines the reality on the ground. For example, the Hindus, far from being a homogenous group, are divided by caste, religious affiliation, place of origin and language. Among the Creoles, there is a divide between fair-skinned and French-speaking Creoles, on the one hand, and dark-skinned and often less educated Kreol-speaking Creoles, on the other (Caroll \& Caroll, 2000; I22). These ethnic differences are further complicated by religious affiliations. While categorised as belonging to the Indo-Mauritian group, Telegus and Tamils, for example, do not identify with the Hindus due to religious differences. 
Although ethnic and religious differences exist, there are also, as in many parts of the world, cross-cutting and overlapping identities in Mauritius. Eriksen notes that "[a] though the correlation between religion and ethnicity is high, Chinese Catholics, Indo-Christians and Muslim Creoles, among others, worship with members of ethnic groups other than their own" (Eriksen, 1996). People who belong to the same ethnic group may thus belong to different religious groups. The same applies to those who belong to the same religious group. The cross-cutting of identity has not created, however, a sense of common identity or belonging across ethnic groups. The practice of a common religion has not, for example, led to a sense of community, thereby, cross-cutting ethnic identities. While a small percentage of the Chinese population is Buddhist, the majority is Roman Catholic. This has not created a common identity with Creoles, who are also Roman Catholics but originate from Africa. Similarly, while the majority of the Franco-Mauritians, descendants of French colonizers, are Roman Catholics, they identify neither with the Creole nor the Chinese population. The layering of identities on the island is thus very complex, with identifying factors overlapping and cross-cutting each other.

\section{Background to the adoption of the Best-Loser System}

As Mauritius was moving towards independence, eventually freeing itself from roo years of British colonization, there were anxieties regarding the management of its plural society (Caroll \& Caroll, 2000). The Hindu community was, of course, less apprehensive about independence. As the community that accounts for the majority of the population, they were confident that they would be able to dominate politically. Others and more specifically, the Creoles, on the other hand, opposed independence, fearing Hindu domination in an independent Mauritius. Muslims also shared the same concern. Independence was seen as a threat to the well-being of members of both the Creole and Muslim community. As a result, the absence of a Pan-Mauritian identity was palpable:

In the years following independence, very few people thought of themselves as 'Mauritians'. They were Creoles, or Muslims, or Indians (meaning Hindus who spoke Hindi or Bhojpuri), or Telegus, or Tamils, or Chinese, or French, who happened to live on the island of Mauritius government's policy was always assessed first and foremost on the basis of its effects on each citizen's particular identity group. Effectively, politics was seen as an inter-group competition in which vigilance was essential if members wished to get their 'fair share' of benefits. Appeals for sacrifice or restraint in the national interest were seldom heard, simply because they would have been so alien to Mauritian society (Caroll \& Caroll, I999; I84-I85).

Even before the advent of independence, the management of ethnicity proved to be a thorny issue. One of the contested issues was the electoral system that independent Mauritius must adopt. Minority groups, especially the Muslim community, were wary of any electoral system which would allow for a Hindu-hegemony and which would leave them unable to access power. The Muslim community wanted completely separate electoral lists for the four communities, which would then ensure that proportionately with their 
size, II out of the 60 seats available in the National Assembly would always be occupied by Muslims. This proposition was, however, rejected (Srebnik, 2002; 278). A proposal by the British minister for the colonies to introduce a system of proportional representation, with a view to providing adequate representation for minorities, was also withdrawn in 1956 after it faced strong objection from the majority Mauritius Labour Party (Mathur,I997; 76).

British electoral commissioners, notably Sir Malcolm Trustram-Eve and Harold G. Banwell, guided by S.A. De Smith, were given the task by Britain of devising an electoral system, which would ensure the adequate representation of all ethnic groups (Mathur, I997; 6I). In I966, the Banwell Commission proposed a modified electoral system combining elements of first-past-the post (FPTP) and proportional representation. The system of proportional representation was to ensure the representation of minorities in parliament. Five seats were to be allocated to the best losers from under-represented communities, subject to the political party securing at least ten percent of the votes at national level and one seat through the FPTP system (de Smith, I968; 609). This electoral system was rejected by the political parties as it would have forced minorities to either merge with parties having a strong Hindu base or to accept their exclusion from political power.

A modified version of the Banwell electoral system was then proposed by John Stonehouse, the Parliamentary Under-Secretary for the Colonies. He proposed an electoral system, which would provide for the majority of parliament to be elected through the FPTP and, in order to correct any ethnic imbalance, allows for the allocation of eight seats to the best losers of the appropriate community. BLS allows for ethnic balance by providing additional seats to under-represented communities in parliament. His proposal took away the requirement of a minimum percentage vote and of at least one directly elected member (de Smith, I968; 6ro). This modified proposal was accepted by the political parties. Based on this formula, elections were held on 7 August I967, marking the introduction of BLS in the Mauritius electoral system.

\section{The functioning of the Best-Loser System}

The functioning of BLS is described in the First Schedule of the Constitution. Generally speaking, members of parliament are elected both through the system of first-past-the post and BLS. After 62 members have first been elected through the FPTP system (three members from the twenty constituencies in Mauritius and two in Rodrigues), a maximum of eight seats are allocated through BLS by the Electoral Service Commission to ensure a fair and adequate representation of Mauritian society, which, for the purpose of the electoral system, is divided into four communities: Hindu, Muslim, Sino-Mauritian, and those that belong to the General population. General population is a residual category. Anyone who does not feel they belong to any of the three groups is described as belonging to the General population. In practice, the General population comprises three categories of Mauritians: first the Franco-Mauritians (the 
whites), second, the coloured or mulattos, and third, the Creole (blacks). ${ }^{\mathrm{I}}$

How are the eight seats allocated through BLS? The basic rule underlying the system is to guarantee seats for ethnic minorities, irrespective of the elections results. "Should the proportions of elected members be less than that community's percentage of the population, 'best losers' - that is candidates from under-represented ethnic communities who stood for elections for recognised parties but who were defeated - make up the difference" (Srebnik, 2002; 278). Based on this principle, the first four seats are allocated in consideration of community and suffrage. In other words, the first four seats are allocated to the most successful unreturned candidate belonging to the appropriate community, the term used to describe the most under-represented community. To ascertain which community is under-represented, the total number of persons belonging to a specific community, as indicated in the 1972 population census, is divided by the number of elected members, plus one. This calculation is repeated for all the four communities. The calculation gives an indication as to how many members of a particular community are represented by single MP that belongs to the same community. The community with the highest quotient is deemed the most under-represented. Individual parliamentarians from the community with the highest quotient are deemed to represent more electorates than parliamentarians from other communities. For example, the Chinese community would be the most under-represented community if each parliamentarian of Chinese origin represents 30,000 electors, while parliamentarians from other communities represent fewer than 20,000 electors individually (Mathur, I997; 63). The most successful unreturned candidate would be a candidate from the most under-represented community that has obtained the highest percentage of votes when compared to candidates from the same community. This calculation is repeated for each of the four seats.

The same calculation is used to allocate the second set of four seats to the most under-represented communities. The difference is that in order to be considered for the remaining seats, the candidate must not only belong to the most under-represented community, he or she must also belong to the political party that has secured the highest percentage of national votes. The second set of four seats is thus allocated based on community, suffrage and the electoral strength of the political party. The reason behind the limitation of the remaining four seats to the most successful party or coalition has to do with a desire to avoid the distortion of election results. By compensating the successful party or coalition for any of the first four seats allocated to other parties, it seeks to prevent an undesirable political scenario, in which BLS changes the winner of an election or creates political imbalance, especially in cases where the elections have been won by a small majority (Seegobin, 2009; 4 ). ${ }^{2}$ It must also be noted that the allocation process

T. Eriksen in 'Us and them in modern societies- ethnicity and nationalism in Mauritius, Trinidad and beyond' cited in Parvez Carrimkhan v. Tin How Lew Chin (2000).

2 The safeguard does not, however, completely help to avoid the distortion of electoral results and ensure that the winning party or coalition retains the majority in parliament. The method for allocating the second set of seats, which is on a step-by-step basis, may reverse the results of an election in case of a wafer-thin victory. In a case where a party wins by a narrow majority of two seats and the first four seats are allocated to the losing party 
continues until it proves impossible to find a losing candidate that belongs to the appropriate community and the successful party or coalition. This means that the Electoral Commission does not necessarily allocate all eight seats.

\section{Implications of the use of the Best-Loser System for communal relations}

As mentioned earlier, the primary objective of BLS is to ensure communal balance in parliamentary representation. It is designed to ensure the inclusion of minorities in the most important public decision-making body. As the submission of the state of Mauritius before the UN Human Rights Committee reveals, "the objective of the system is to ensure that the multi-ethnic and multi-religious nature of the state is reflected in its National Assembly". 3 The intended end result is thus a parliament that is characterised by balanced communal and ethnic representation.

The functioning of BLS is, however, plagued by a number of controversies. A call for electoral reform is common. Frustrated by the lack of political will to reform the electoral system, many have also resorted to the courts to challenge the validity of BLS. The use of the 1972 census to ensure appropriate communal representation has, for example, been the subject of criticisms. As mentioned earlier, the most under-represented community is determined based on a calculation that relies on the 1972 population census, the last census in which the respondents were asked to indicate their ethnic affiliation. The grounding of ethnic representation on a census that was conducted more than four decades ago undoubtedly raises questions as to both the appropriateness and veracity of the allocation of seats. Many are worried that the apportionment of seats that is based on the census of 1972 "no longer reflect the shifts in the ethnic composition of the population" (Srebnik, 2002; 279). How accurate can a census that is more than four decades old be, they ask. ${ }^{4}$ The Supreme Court of Mauritius has expressed its reservations on the use of the 1972 census. The fact that the allocation of best losers seats "in the year 2000 will apply the figures of the 1972 Census creates a situation which may not reflect reality". ${ }^{5}$ This was also a sentiment shared by the United Nations Human Rights Committee, which was asked to determine whether BLS is inconsistent with the obligations of Mauritius under the International Covenant on Civil and Political Rights. ${ }^{6}$ In its decision, the Committee "noted that

and none of the second set of four seats is allocated due to the unavailability of candidates from the appropriate party and community, the losing party will become the majority party by two seats. Although such situation has not arisen to date, it is theoretically possible. Furthermore, by granting the first four additional seats to the opposition party, BLS may also affect the margin of manoeuvre available to the winning party. A change in the weight of the support commanded by the winning party in the National Assembly may impact on the ability of the government to amend or repeal sections of the Constitution. Amending some sections of the Constitution requires either a two-third or a three-quarter majority. See Mathur, I997; 44. 
community affiliation has not been included in a census since 1972" and urged the state to "update the 1972 census figures on community affiliation". ${ }^{7}$

Notwithstanding the controversial issues surrounding the use of the 1972 census, one of the most important questions regarding BLS is, for our purpose, its impact on inter-communal relations. This is about the implications of the use of BLS as an inclusionary mechanism. The question is whether BLS has contributed to the harmonious co-existence of communities or exacerbated the same communal divisions that it was supposed to help manage.

One of the main criticisms levelled against BLS is that it crystallises ethnic identity and ultimately promotes communalism in Mauritian society. Some describe the system as the "consecration of communal considerations in constitutional terms" ${ }^{8}$ It is an electoral system that, for many, 'legitimises/institutionalises the process of political ethnicisation' (Kadima \& Kasenally, 2005; I43). At the centre of this claim is the obligation that BLS imposes on every candidate to indicate community affiliation in the nomination paper.

For BLS to function properly, every candidate must declare to which community he or she belongs. According to the law, the candidate's nomination, as mentioned earlier, is declared invalid if the candidate has failed to declare on the nomination papers the community to which he or she belongs. The Supreme Court of Mauritius has, on a number of cases, ruled that "there is a legal obligation for candidates to declare on their nomination papers to which community they belong and that without this information the nomination is invalid". 9

it is not based on objective or reasonable criteria. The impact of the ruling might however be considered to have been lessened by two factors. First, the Committee took great care to highlight that it was not 'expressing a view as to the appropriate form of the State party's or any other electoral system'. Secondly, the remedy proposed by the Committee was to require the state to update the 1972 population census, as far as community affiliation is concerned and to reconsider the need for a community based electoral system. It seems that while the Committee considered the mandatory classification as being in violation of the Covenant, the Committee was wary of being seen as interfering in the electoral system of a state party.

$7 \quad$ Narain et al $v$. Mauritius. However, although indisputably more accurate, a new census would create challenges. Any change in the weight of the communities, which will unavoidably impact on representation through BLS, will provoke strong feelings among some communities. A community with a reduced level of representation will certainly feel anger and fear, two emotions with possibly explosive consequences in a multi-ethnic country. This raises the general problem of reforming electoral systems that take the population size of communities into account. T Fearing that an update of the 1972 census would open a Pandora's Box, both the Head of the Government and the leader of the Opposition have opposed such a course of action. In fact, in his 20I3 New Year's address to the public, the Prime Minister rejected the electoral reform required by the HRC on the ground that it would exacerbate communal divisions among the population. (l'express dimanche, 2012 ;2I). For him, "[i]t is "hors de question"... to enhance and modernise the Best Loser System by updating the census referred to in the definition of the 'appropriate community'. In fact updating the census at this point would amount to a step backward".

8 Sir Gaetan Duval v. Francois (I982) as quoted in The Electoral Supervisory Commission v. The Honourable The Attorney General (2005); 7. See also Kadima \& Kasenally, 2005; 150 who argue that the system represents a 'process of deliberate ethnicisation.

$9 \quad$ Narain et al v. Mauritius; I. See also The Electoral Supervisory Commission v. The Honourable The Attorney General (2005). There is, however disagreement regarding the effect of non-declaration of community affiliation. A number of cases were brought before the Supreme Court challenging the constitutionality of the decision to nullify the nomination. In one case, the Supreme Court ruled that the sanction of nullity of a candidate's nomination in case of non-declaration of community in a situation where the candidate is not to appear as a candidate to be elected as best loser was an unjustified curtailing of a citizen's right to participate in an election. The Court held that 'the right to stand for election is so fundamental for the existence of a true democracy that it cannot 
The candidates must choose between the Hindu, Muslim or Sino-Mauritian community. If the candidate, based on his or her way of life, cannot be categorised as belonging to any of the three communities, the candidate is then deemed to belong to the General Population. ${ }^{\text {Io }}$ The 'General Population' category is effectively 'a residual category', absorbing "all those whose way of life shows that they do not belong to the first three communities". ${ }^{\text {II }}$

Related to this obligation of declaring one's affinity is the problem of determining membership to a particular community. How is membership determined? According to the Constitution, community affiliation is determined based on one's way of life. According to the Supreme Court of Mauritius, "way of life may depend on a series offactors - the way one dresses, the food one eats, the religion one practises, the music one listens to, the film one watches". The Court has further added that "[e]xternal appearance and the name one bears are also pointers as to the community to which one may belong". ${ }^{12}$

Despite the use of the 'general population' category as a residual category and the exposition of the 'way of life' criterion by the Supreme Court, many, including those who brought cases before the courts, have argued that they were unable to categorise themselves as belonging to any of the four groups. In the case that was brought before the UN Human Rights Committee, for example, one of the central arguments made by the applicants was that 'the way of life' criterion, which is the basis for the classification of communities, is vague" ${ }^{13}$ The courts in Mauritius have also, on a number of occasions, declared the

be tampered with'. Narain v. Electoral Commissioner (2005). In another related case, the Supreme Court similarly held that " $[\mathrm{d}]$ isqualifying an otherwise qualified person from standing as candidate on the sole ground that he has failed to declare his community imposes an unreasonable and unjustifiable fetter to this fundamental right [i.e. the right to stand as a candidate) which right is at the very cornerstone of democracy and should be jealously guarded and preserved". See Marie v. The Electoral Commissioner (2010) SCJ I38. The ruling was, however, a short-lived victory for those that rejoiced over the nullification of paragraph (5) of Regulation I2, which renders void a nomination made without the declaration of community affiliation. The decision was later reversed by a Full Bench of the Supreme Court. In The Electoral Supervisory Commission v. The Attorney-General, the Full Bench of the Supreme Court, while recognising the inherent difficulties posed by BLS, held that the identification obligation and the subsequent invalidation of the nomination paper do not infringe section I of the Constitution. The declaration of community lies at the heart of BLS system and any reform to the electoral system should be, according to the Full Bench, the work of the legislator, and not the doing of the court. This, the court argued, is especially true considering that any change to BLS requires a weighted two-third majority. The Electoral Supervisory Commission v. The Honourable The Attorney-General (2005). In 2010, the Marie v. The Electoral Commissioner case brought back the declaration of community into the spotlight, by arguing that Regulation 12 of the National Assembly Elections Regulations I968 is ultra vires section I of the Constitution. While the Judge proved very sympathetic to the arguments put forward by the applicants, he held himself bound by the 2005 decision reached by the Full Bench and set aside the application. Marie v. The Electoral Commissioner (2010).

Art 3(4), First Schedule of the Constitution. As correctly noted by Eriksen, the General population does not represent a distinct socio-cultural group. (Eriksen, I992; 76). Some, however, hope that "it could eventually constitute a united Mauritian community" Parvez Carrimkhan v. Tin How Lew Chin (2000); 20. Parvez Carrimkhan v. Tin How Lew Chin (2000); II. See also Narain et al v. Mauritius; I.

I2 In Parvez Carrimkhan v. Tin How Lew Chin (2000), the applicants relied, among other things, on the names of the candidates to challenge the correctness of their declaration relating to their community on their nomination paper for the general election. According to the applicant, "the names of the [candidates] were indicative of the fact that they did not belong to the community stated in their declaration". But the Court has also indicated that names are not a decisive factor in determining the community to which one belongs; "[N]ames by themselves, although they may offer a primary indication of the way of life of a person, are not a determining factor" (Parvez; 15).

Narain et al v. Mauritius; I. Some argued that the reference to community for the purpose of the best loser sys- 
criteria to be 'not only unrealistic but altogether unworkable'. The 'unworkability of the criterion' becomes apparent, the court argued, even before one resort to the residual category. It will become apparent "in the first place in the determination of whether someone's way of life does or does not show that he belongs to the Hindu, Muslim or Sino-Mauritian communities". ${ }^{14}$ The determination of one's belongingness is further complicated by the life style that a class distinction brings. As the Supreme Court of Mauritius has noted, "a way of life can also be dependent on class distinction, for a rich Hindu and a rich Sino-Mauritian may have a similar way of life, depending on their financial means, whereas a rich Hindu and a poor Hindu may lead altogether different ways of life" ${ }^{15}$ Furthermore, others argue, the division of Mauritius society into the four population groups "does not correctly reflect the reality about the population of Mauritius which, independently of its various origins, has developed an intrinsically Mauritian way of life, which cuts across cultural boundaries". ${ }^{16}$

The problem surrounding the difficulty of determining membership of a particular community has also made the system vulnerable to abuse. It seems that politicians have learned how to use the system to their advantage. In the last general elections of 20Io, a member of the Chinese community, Michael Sik Yuen, decided to declare himself as a member of the General Population on his nomination paper. This was viewed with suspicion by many politicians and members of the public. Based on his name and the important position and high esteem with which his family is held in the Chinese community, many regarded him as belonging to the Chinese community. ${ }^{17}$ The decision to declare General Population as the community to which he belongs was motivated, it is widely argued, by the higher prospects of obtaining a seat in the National Assembly through the best-loser system as a member of the General Population as opposed to a member of the Chinese community. In fact, the candidate eventually managed to join parliament through BLS as a member of the General Population. A glance at his political activities since joining parliament would, however, reveal that he more often than not acts as a representative that is mandated to protect and voice the interests of the Chinese community. ${ }^{18}$

tem is a reference to a community according to one's religious affiliation. In the case of Parvez Carrimkhan v. Tin How Lew Chin \& Ors. i.p.o The Electoral Commissioner (2000) the counsel for the applicant argued that “ 'community' is a body of people having a religion in common". This was rejected by the judge. The judge emphasises that there is nothing in the schedule that suggests that 'appropriate community' means "the religious community" that the Constitution refers to in Section II. "There may be dozens of religious communities in Mauritius but there are only 4 appropriate communities". After all, the judge indicated, "a Sino-Mauritian may be a Buddhist or a Christian (or a Mauritian whose ancestors are of Indian origin may be a Catholic)". "What paragraph 3(4) of the Schedule purports to do is to divide Mauritians into communities only "for the purpose of this schedule". Parvez Carrimkhan v. Tin How Lew Chin \& Ors. i.p.o The Electoral Commissioner (2000); Io.

I4 Narain v. Electoral Commissioner (2005).

I5 Parvez Carrimkhan v. Tin How Lew Chin \& Ors. i.p.o The Electoral Commissioner (2000).

I6 See Narain $v$.Electoral Commissioner 2005; 6.

I7 For example, Michael Sik Yuen, together with two other candidates of Chinese origin, met members of the Chinese community at a private member club created for and by the Chinese community during the electoral campaign. (L'express, 2014). 
The election of Michael Sik Yuen raised the question as to whether it was moral or even legal for a candidate, who for all intents and purposes is representing a specific community, to benefit from a best-loser seat reserved for another community due to a community affiliation declaration that is dishonest. To be precise, Michael Sik Yuen has not breached the law. The General Population category is a residual category and anyone who, based on his or her way of life, feels that he does not belong to any of the other three communities can legitimately be considered as a member of the General Population. However, the concern that the system can be used as instrument of political strategy remains valid.

The choice of a community by prospective candidates has also been the subject of court proceedings. Over the years, numerous cases have been lodged before the courts challenging this particular element of BLS. ${ }^{19}$ In this regard, one of the first cases to reach the Supreme Court of Mauritius was Parvez Carrimkhan v Tin How Lew Chin..$^{20}$ In that case, the candidates had chosen their community through the drawing of lots. ${ }^{2 \mathrm{I}}$ The Judge, unable to decide which community each candidate belonged to, ${ }^{22}$ classified all of them as belonging to the General Population. This and the several challenges brought before the courts reveal that the obligation to indicate community affiliation makes identity an ongoing issue in the political and legal arena of Mauritius. This is evident in the number of cases brought before the courts challenging the correctness of declarations made relating to community affiliation. There are also some doubts about the exercise of determining the community to which a candidate belongs, when the truthfulness of a candidate's declaration of community affiliation is challenged by others. This is particularly troubling in a situation where the candidates do not subjectively feel that they belong to any of the three communities. It brings to fore the question whether an individual's identity is determined solely based on some objective criteria, which would be the case of ascribed identity. It also reveals the unenvious position that the court finds itself in discharging the difficult task of determining the way of life of members of the Hindu, Muslim and Sino-Mauritian communities.

I9 According to the Constitution, every electorate has the right to challenge the community chosen by a candidate before the Supreme Court, showing the importance placed on the accuracy of the choice of community. The majority of these cases challenged the constitutionality of the identification obligation vis-à-vis the Constitution. The rest of the cases were concerned mostly with the choice of community by the candidates. See Article 3(2) First Schedule to the Constitution of Mauritius.

Parvez Carrimkhan v. Tin How Lew Chin (2000).

2I In earlier years, candidates belonging to the small radical socialist party Lalit ('The Struggle') initially refused to indicate their community affiliation and later proceeded to draw lots' determining their community affiliation. As Eriksen notes, "the result was not devoid of Theater of the Absurd qualities... [in which]...one of their leaders, to all appearances a white Mauritian of foreign birth, turned out to be a Hindu on the election rolls" (Eriksen, I997; I78).

22 The candidates refused to engage the court on details regarding their way of life. They did not file affidavits and the court was only able to obtain information from those that were subjected examination on personal matters regarding their way of life. "When questioned about their way of life most of the Respondents have stated that they live as other Mauritians do. They do not find that they are different. Their names do not mean anything to them because they did not choose them, they were attributed to them by their parents at the time they were born" $12-13$. 
Obviously, the decision to decide community affiliation by drawing lots was a deliberate move to symbolise their objection to BLS. They reject the division of Mauritius into different communities. They emphasise 'the existence of a single community in Mauritius' and regard themselves "to be citizens of the Republic of Mauritius and belonging to the Mauritian Community". ${ }^{23}$ They maintain that BLS institutionalises ethnicity. Based on this, they call for the abolishment of the system.

The problem with the argument for scrapping the system on the grounds that it exacerbates communal divisions, is that it neglects the reason why BLS was adopted in the first place. BLS was adopted because of the fundamental differences that needed to be accommodated. As mentioned earlier, as Mauritius moves into the post-colonial era, some communities were concerned about their fate in the new constitutional and political dispensation. They were particularly anxious about the political dominance of the numerically dominant Hindu community. BLS has responded to the anxieties of these minorities by bringing them into the national political process.

Although none of the political parties are explicitly ethnic-based parties, the major political parties have a particular ethnic group as their stronghold. While the Labour Party and the MSM (Mouvement Socialist Mauricien) have a largely Indo-Mauritian support, the MMM (Mouvement Militant Mauricien) attracts mostly Creoles and Muslims (Kadima \& Kasenally, 2005; I43). In a purely first-past-the-post system (FPTP), the expectation would be that these political parties would focus on their ethnic constituencies where the likelihood of them winning an election is strong. There would be less incentive for them to cast their net wide and appeal to Mauritians outside their 'ethnic bases'. The electoral system in Mauritius is not, however, purely FPTP. It is complemented by BLS, which has, over the years, shaped both political and electoral behaviour. A political party wishing to obtain the maximum number of seats and therefore the majority in parliament must consider the seats allocated under BLS in its political calculations. This has prompted political parties to include candidates belonging to different communities on their party list in order to secure a maximum number of seats in parliament.

BLS has also encouraged political parties to form multi-ethnic coalitions, allowing them to go beyond a party's specific ethnic-base. By entering into coalitions with parties with a different ethnic party base, political parties have been able to create diversity on their party lists and attract the votes of members of different communities. This is also helped by the realisation on the part of the political parties with a Creole or Muslim base that it is virtually impossible for them to win elections without entering into some sort of partnership with political parties that claim to represent the Hindu community (Caroll \& Caroll, I999; I9I). As Kadima and Kasenally noted, "[c]oalitions have usually taken the form of ethnic accommodation" (Kadima \& Kasenally, 2005; I62).

Furthermore, it is probably due to the fact that BLS encourages coalitions across communities that an individual from a minority was able to assume the highest political office in the country. In the general elections of 2000 Paul Berenger, a Franco-Mauritian 
and Anerood Jugnauth, a Hindu, brokered an agreement. According to the agreement, Jugnauth served as the Prime Minister for the first three years while Berenger served as the Minister of Finance. For the last two years of the term, Jugnauth became the ceremonial President and Berenger moved to the office of the Prime Minister. It is doubtful whether Berenger, a Franco-Mauritian, a community that accounts for a mere two percent of the population, would have acceded to power without the support of the Hindu community. It is also doubtful whether Berenger would have been encouraged to enter into such agreement in the absence of BLS. ${ }^{24}$

From the foregoing, it is clear that BLS has facilitated the integration of minorities into the national political process. Thanks to BLS, minority groups are thus assured of their continued inclusion in political power. ${ }^{25}$ The remaining question is whether BLS is still relevant in today's Mauritius. It is this same issue that the Human Rights Committee asked the Mauritius government to consider when it made its ruling in Narrin et al $v$ Mauritius. The government of Mauritius should, in the words of the Committee, "consider whether a community based election system is still necessary". ${ }^{26}$

There are many who believe that BLS has lost its relevance. For Raj Mathur, BLS system is based on the premise that Mauritians still vote along communal lines and that members of parliament represent only their own community (Mathur, I997; 75). This, he argues, might have been true in the early years of independence. To insist, however, that Mauritians today still vote along communal lines is a mis-representation of the sociopolitical reality that characterises the Mauritian society. This view maintains that since I976, communal differences have played little role in how Mauritians cast their ballot (Mathur, I997; 74). The same is true with electoral candidates, who, unlike in the early years of independence, make little or no explicit communal appeal to secure votes (Caroll \& Caroll, I999; I9I). The National Economic and Social Council (NESC), whose aim is to support civil society participation in the national decision-making process, has also argued for the removal of any mention of ethnicity in the Constitution. According to the Council, BLS, having served its purpose of cushioning minorities and preserving communal harmony in ten elections, must now be abolished (NESC, 2012; 6).

The move towards integration of the different communities is also evident, many argue, from the fact that attempts to play the ethnic card receive less and less support among members of the Mauritian society. In 1995, the government proposed the consideration of selected 'oriental languages', including Hindu, as a requirement to obtain admission at a secondary school. This was , unsurprisingly, opposed by members of the Creole community that 'had no ancestral oriental language'. For them, it represented a

\footnotetext{
24 The study by D Kadima \& R Kasenally (2005; 154) has revealed that many believed that the driving force behind political party coalitions formations and the selection of affiliate parties is the accommodation of ethnic diversity: "Each coalition ascertains that it is seen as ethnically representative, an important requirement for social cohesion". Kasenally (2005; I42,152), by choosing political partners based on ethnicity rather than common ideologies, politicians are being hypocrites and calculative as their only aim is to retain or access power. 
naked policy of preferential treatment that was intended to advantage Indo-Mauritians and Sino-Mauritians. However, what is most noteworthy is that the opposition to this particular proposal not only came from members of the Creole community. As Caroll and Caroll noted, "many people from other communities also opposed the measure because it struck them as a blatant attempt by an unpopular government to inject communalism into party politics by 'playing the Hindu card' with the hope of regaining re-election" (Caroll \& Caroll, I999; I84). In fact, many attribute the heavy defeat of the ruling party in the I995 election, in which it lost all of its seats in the National Assembly, to this particular policy (Caroll \& Caroll, I999; I84). ${ }^{27}$ The point is that communal differences do not matter as much as they did in the past. This, it is further argued, is also supported by the fact that ethnically-defined parties that claim to represent only a specific community, such as the Tamil Tigers and Les Verts Fraternels, have had limited success at ballot box (Kadima \& Kasenally, 2005; I43).

The offshoot of these arguments is that BLS is based on the outdated view of the Mauritian society. It is based on the view that regards Mauritius as a simple ensemble of communal groups. It is a system that had relevance in the outdated notion that Mauritius as a society is divided along communal lines. It is a system that belongs, according to this view, to a bygone era of communal division. Although it would be an exaggeration to hold that Mauritius has moved beyond ethnic or religious considerations in politics, this view maintains that there has undoubtedly been, over the past years, a move towards the development of a Mauritian identity. Crude ethnic politics are becoming a thing of the past; so much so that the effects of BLS in today's Mauritius are deemed to be marginal. As a result, the time may be ripe for the reform of the electoral system through the repeal of BLS. After all, so the argument goes, it is important that any electoral system be perceptive and responsive to the changes that the society has undergone. It was this sentiment that was echoed by the Prime Minister when he addressed parliament in 2012 in relation to a question that was raised by the leader of the Opposition on the use of the 1972 census and BLS: "I have said, Mr. Speaker, Sir, time and time again that I believe that the Best Loser System has served us well and has now perhaps outlived its usefulness". ${ }^{28}$

It may be true that Mauritius has made significant progress in integrating its once divided communities. ${ }^{29}$ It may no longer represent the divided society that it once was. Does this, however, mean that inclusive institutions such as BLS that made the transition possible are no longer relevant? Acceding to this view would require adopting a 'transitory view of inclusive institutions'. It requires viewing BLS as a temporary measure that is put in place to address specific oppression or systemic discrimination. BLS was not,

27 The policy was eventually declared unconstitutional by the Supreme Court.

28 Prime Minister replies to private notice question and parliamentary questions of 23 October 20I2, available at http://primeminister.gov.mu/English/Documents/PM\%20In\%2oParliament/PNQ_PQ_23October.pdf.

29 One must, however, note that not everybody agrees with this sentiment. In fact, Kasenally (20II, 37) founds Mauritian politics to be paradoxical: "At one level, it promotes a very broad-based approach to ensuring that all ethnic groups are included in what are termed 'rainbow-nation alliances'. Concurrently it also encourages ethno-religious politics, where appeals are made to groups to support those of their kind." She specifically alludes that "in the past four decades, ethno-religious politics has transformed itself from a relatively benign to a more insidious process, with grave ramifications for social harmony and diversity on the island" (Kasenally, 20II, 38). 
however, adopted 'as a remedy for a form of oppression' that must be eliminated when the oppression or systemic discrimination is removed. BLS was adopted to ensure the continuous inclusion of minorities in the national political process of multi-ethnic Mauritius. Furthermore, accomodationist elements of a constitution like BLS should not be transitory in nature. They are built based on the premise that a multi-ethnic society must always ensure that the different groups are provided with the means for political participation and representation.

It is not also clear that the BLS system has contributed to the crystallization of communal identities. In fact, the argument that Mauritius has moved away from the era in which it was seen as a divided society and no longer requires BLS casts doubt on the claim that the latter has further entrenched communal divisions. In the presence of the policy of BLS, Mauritians and their politics are gradually moving away from the politics of identity. It therefore defies logic to call for the abolition of BLS on the grounds that it promotes communalism. Furthermore, much of the talk related to BLS and communalism ignores the fact that the communities used for the purpose of BLS do not exactly correspond to the communal differences that characterises Mauritian society. The official population groups recognised for the purpose of a general election do not reflect a fault line that characterises the Mauritian society. Both the labels of 'Hindu' and 'General Population' do not reflect the stratification and differentiation that characterises these two communities, be it in terms of culture, language or ethnicity (Nave, n.d; ro). ${ }^{30}$ Therefore, to assign cultural and religious divisions in Mauritian society to BLS-related classification of communities might not be completely accurate.

Perhaps it might be as a result of the inclusive nature of the state, owing to countermajoritarian settlement such as BLS and other similar inclusive measures that the different communities in Mauritius have been able to move closer to the development of a sense of community. In fact, the World Bank Report states that "the best loser system, by ensuring representation of each ethnic group in parliament, has contributed to the social cohesion in Mauritius" (cited in Suntoo \& Chittoo, 2012; 38). What Mauritius might be witnessing is thus the emergence of a sense of solidarity out of a process that acknowledged that every community has a place at 'the Mauritian table'. ${ }^{\text {I }}$ This says that it is the recognition of the diversity of the people of Mauritius that is eventually giving rise to more integrated communities. One must therefore be cautious about dismissing the relevance of inclusive institutions such as BLS as such an attitude may well undermine the move towards a more united Mauritius.

Finally, one must not discount the symbolic significance of maintaining inclusive institutions such as BLS. Even if in real terms the contribution of BLS might be negligible, the continued existence of BLS in the Constitution is, at least, symbolically speaking,

"What paragraph 3(4) of the Schedule purports to do is to divide Mauritians into communities only "for the purpose of this schedule". Parvez Carrimkhan v. Tin How Lew Chin \& Ors. i.p.o The Electoral Commissioner (2000); ro.

3I Deborah Brautigam maintains that it is the 'modified consocitionalism', 'which allowed for the inclusion of all of the major ethnic groups in the political system', that has 'enabled democratic consolidation to proceed.' A well-crafted political system, she writes, 'can ensure broad representation while providing incentives for coalition building, moderation and compromise'. As quoted in Srebrink, 2002; 289. Brautigam, I997; 53, 59. Brautigam, I999; I58). 
a reassuring mechanism for minorities. As noted by some, "[t]he BLS, as a constitutional provision, acts positively on the psyche of the minorities who feel secure" (Suntoo \& Chittoo, 2012; 33). It symbolises the inclusion of all communities and the recognition of their importance on the national scene. Its importance lies, therefore, in its symbolism, which says that each community has a 'place at the table'. The removal of BLS could be construed as a strong repudiation of that symbolism. This could have drastic consequences as symbols are as important as reality when it comes to matters of ethnic relations (Caroll \& Caroll, I999;I92). If you take away BLS, then there may be an increased risk that communal differences will become more pronounced in the political arena.

\section{Conclusion}

Adopted before independence was granted, to allow for the representation of all communities in parliament, BLS has undoubtedly fulfilled its role. This unique and complex system has ensured the consistent presence of all communities at the highest political level, thereby reassuring minority groups as to their importance and inclusion into the Mauritian political system. It is in this sense that BLS has been hailed as one essential ingredient that has helped to build a relatively stable and united multi-ethnic Mauritius.

For reasons explained in this article, however, electoral reforms have continuously been on the political agenda of Mauritius. Seven reports and commissions have looked at BLS: three of them before independence and four since 2000 (Electoral Reform Unit, $2014 ; 4)$. One Commission which garnered massive attention, both from the public and

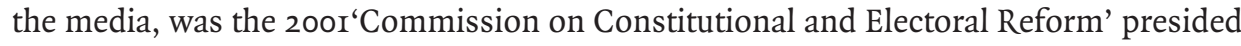
by Albie Sachs, a judge of the Constitutional Court of South Africa at the time. The Sachs Commission recommended dismantling BLS and instead proposed the introduction of Proportional Representation. According to the Sachs Report, the National Assembly should be composed of 62 members elected through FPTP, and 30 additional members chosen from party lists by political parties having obtained at least ten percent support at the national level. This list should be provided beforehand by the political parties. This would allow for ethnic representation, together with a fairer gender representation (EISA, 2005). Despite the considerable investment in the Commission, including the setting up of a 2002 Select Committee to advance the proposals put forward in the Sachs Report, no concrete action was taken (Kadima \& Kasenally, 2005; I50-I5I).

In March 20I4, the Electoral Reform Unit located at the Prime Minister's Office unveiled a consultation paper on the electoral reform. This consultation paper draws heavily on the Sithanen Report, a 2012 report written by a Mauritian economist and former Minister of Finance. The Sithanen Report proposed the retention of the 62 members elected under the FPTP, but proposed the introduction of 20 members elected from a closed party-list based on the aggregate percentage of votes obtained by unreturned party candidates nationally (Electoral Reform Unit, 20I4; 44). The report proposes abolishing the eight best loser seats and creating sixteen new seats based on a system of proportional representation. The argument is that the sixteen additional seats would allow for the representation of ethnic minorities, without, unlike BLS, entrenching of ethnic and 
communal references in the Constitution. Rather, ethnic representation through proportional representation will be ensured through 'a social compact, a consociational arrangement' where political parties are encouraged to ensure the proper representation of ethnic minorities on their party list only because a varied electoral list would appeal to a higher percentage of the population (Sithanen (2012) cited in The Electoral Reform Unit, 2014; 65). The proposed electoral system obviously relies on the political maturity of political parties.

The replacement of BLS by the proposed proportional representation system may not in reality make the electoral system less accommodating. The aim of BLS is to avoid the under-representation of minority communities, ensuring that the proportion of members elected to the National Assembly is not less than the community's percentage of the population. And that is exactly what a proportional representation system seeks to achieve. It seeks to match the percentage of seats a party obtains in parliament with a percentage of the national vote it has managed to secure. In principle, minorities do not have to be necessarily apprehensive over a proposal to remove BLS and replace it with a proportional representation system.

According to the Mauritian Constitution, any electoral reform requires a two-thirds majority support in the National Assembly. However, the problem is greater than the requirement of a two-thirds majority. The challenge lies in the fact that effecting any change in the electoral system involves political risk and hence requires strong political will. Any repeal or amendment of BLS could seriously damage the support enjoyed by a political party. If the political party that advocates removal of BLS has strong support among Hindus, the any change to BLS will be seen as a plan to impose Hindu hegemony on the rest of the population and as a calculated rejection of the concerns of minorities. On the other hand, if the political party has a strong support among minorities, any change to BLS could lead to an erosion of the party's political base. As a result, BLS, as aptly noted by Kasenally (20II, 40), "remains an ultra-sensitive issue that no political leader or party dares address for fear of losing the support of the more vocal members of these ethnic groups". It is most likely for these reasons that while reports and commissions on the review of the electoral system have often been set up, no concrete action has been taken till now. It is often easier for political parties to commission reports, than to act upon the recommendations as any change to BLS may resonate highly within the electorate and is likely to affect the political and electoral influence of the party.

\section{References}

Brautigam, B. (I997). Institutions, Economic Reform, and Democratic consolidation in Mauritius. Comparative Politics, 30(I): 45-62.

(I999). The Mauritius miracle: Democracy, institutions and Economic Development. In R. Joseph (ed), State, Conflict and Democracy in Africa. pp. I37-r62. Boulders, Co, Lynne Rienner Press.

Carroll, B. \& Carroll, T. (I999). The consolidation of democracy in Mauritius. Democratization. 6(I): I79-I97. (2000). Accommodating ethnic diversity in a modernizing democratic state: theory and practice in the case of Mauritius. Ethnic and Racial Studies, 23(I): I20-I42.

De Smith, S.A. (I968). Mauritius: constitutionalism in a plural society. The Modern Law Review, 3I(6): 6oI622. 
EISA (2005). Mauritius: electoral reform: the Sachs Commission. Retrieved from: http://eisa.org.za/WEP/ mausachs.htm.

Eriksen, T. (1992). Us and Them in Modern societies: Ethnicity and Nationalism in Mauritius, Trinidad and Beyond. Oslo: Scandinavian University Press.

(1996). A non-ethnic state for Africa? On integration, disintegration, difference and similarity in contemporary Africa. In ASEN Conference, London, II May 1996.

(1997). Multicuturalism, Individualism and Human Rights: Romancticism, the Enlightment and Lessons from Mauritius. In R. Wilson (ed.), Human Rights, Culture and Context, pp. 173-18I. London: Pluto.

Kadima, D. \& Kasenally, R. (2005). The formation, collapse and revival of political party coalitions in Mauritius: Ethnic logic and calculation at play. Journal of African Elections, 4(I): I33-I64.

Kasenally, R (20II). Mauritius: the not so perfect democracy. Journal of African Elections, IO(I): 33-47.

La Redaction (2010, April 24) Aline Wong, Sik Yuen et Li Kwong Wing rencontrent des mauricens d'origine chinoise. L'express.

Retrieved from: http://www.lexpress.mu/article/aline-wong-sik-yuen-et-li-kwong-wing-rencontrent-des-mauriciens-d\%E2\%80\%99origine-chinoise.

La Rédaction (2012, December 30). Un avant-gout de 2013. L'express dimanche. pp. 2 I.

Marie $v$ The Electoral Commissioner (2010) SCJ 138.

Mathur, R. (1997). Parliamentary Representation of Minority Communities: The Mauritian Experience. Africa Today, 44(I):6I-82.

Narain v Electoral Commissioner (2005) SCJ 159.

Narain et al. v. Mauritius Communication No.1744/2007.

Nave, A. (n.d). Communalism as conflict: Examples from Mauritius. Retrieved from: http://arinave.com/wordpress/wp-content/uploads/2012/05/Communalism-as-Conflict.pdf.

NESC (2012). Electoral reform and social stability.

OSCE ODHIR (200I). Guidelines to assist national minority participation in the electoral process.

Parvez Carrimkhan $v$ Tin How Lew Chin \& Ors. i.p.o The Electoral Commissioner (2000) SCJ 264.

Prime Minister replies to private notice question and parliamentary questions of 23 October 20I2, available at: http://primeminister.gov.mu/English/Documents/PM\%20In\%20Parliament/PNQ_ PQ_23October.pdf.

Seegobin, K. (2009). The human rights implications of the 'best loser system' in Mauritius and prospect of reform. Unpublished master thesis, University of Pretoria, Pretoria, South Africa.

Srebrnik, H. (2002). Full of sound and fury': Three decades of parliamentary politics in Mauritius. Journal of Southern African Studies, 28(2): 277-289.

Suntoo, R. \& Chittoo, H.B. (2012). Managing multi-ethnic Mauritius. Global Journals of Human Social Sciences I2(3): 33-42.

The Electoral Reform Unit (2014). Modernising the Electoral System.

The Electoral Supervisory Commission $v$ The Honourable The Attorney General (2005) SCJ 252.

Yusuf, S. (2012). Mauritius: Growing a small island economy. 